
Indonesia)

\title{
Pengaruh Kampanye Go-Pay Day Food and Beverage terhadap Perilaku Konsumtif Pengguna (Survei Pada Karyawan P.T Pionir Maxima Mutu Indonesia)
}

\author{
Cyntia Triana Simanjuntak, H.H. Daniel Tamburian \\ Cyntiajuntak18@gmail.com,danielt@fikom.untar.ac.id \\ Fakultas Ilmu Komunikasi Universitas Tarumanagara
}

\begin{abstract}
The title of this research "Campaign Influence Go-Pay Pay Day food and beverage To The User's Consumptive Behaviour (Surveyed to one of the employees of P.T Pionir Maxima Mutu Indonesia)". In this research, 100 respondents were participating in filling up the questionnaire by using a google form, where the terms and conditions to be a respondent is using Go-Pay on the Pay Day Food and beverage. The purpose of this research is to discover the impact of the campaign of Go-Pay Pay Day food and beverage towards Consumptive behaviour user.This research identifies the impact of the campaign Go-Pay Pay Day food and beverage towards Consumptive behaviour user and the cause of the user's consumption in using Go-Pay on the Pay Day food and beverage. This research also utilizes correlation methods which are gatherers data to determine if there are relations and the level of relationship between the two variables. The data of the research has been obtained from the questionnaire, literature review, journal, and online data. The theory that has been used in this research was The Theory of Communication, Campaign and Consumptive Behaviour. The result of this showing the campaign of Go-Pay Pay Day food and beverage has a positive impact and significant effect towards the Consumptive Behaviour on the employee of P.T Pionir Maxima Mutu Indonesia.
\end{abstract}

Keywords: campaign, correlation, consumptive behavior

\begin{abstract}
Abstrak
Penelitian ini berjudul "Pengaruh Kampanye Go-Pay Pay Day food and beverage terhadap perilaku Konsumtif Pengguna (Survei Pada Karyawan P.T Pionir Maxima Mutu Indonesia)". Penelitian ini mengambil sampel 100 responden dengan penyebaran kuesioner menggunakan google form, dimana syarat menjadi responden adalah populasi yang menggunakan Go-Pay pada saat Payday food and beverage. Tujuan penelitian ini adalah untuk mengetahui pengaruh Kampanye Go-Pay Pay Day food and beverage terhadap Perilaku Konsumtif Pengguna. Penelitian ini mengidentifikasi masalah pengaruh kampanye Go-Pay Pay Day food and beverage terhadap perilaku konsumtif pengguna serta Penyebab konsumtifnya pengguna dalam pemakaian Go-Pay pada saat Pay Day food and beverage. Penelitian ini menggunakan metode korelasi yaitu penelitian yang melibatkan tindakan pengumpulan data guna menentukan, apakah ada hubungan dan tingkat hubungan antara dua variabel. Data penelitian diperoleh dari kuesioner, studi pustaka, jurnal, dan data online. Teori yang digunakan dalam penelitian ini adalah Teori Komunikasi, Kampanye dan Perilaku Konsumtif. Hasil penelitian menunjukkan Kampanye Go-Pay Pay Day food and beverage memiliki pengaruh positif dan signifikan terhadap Perilaku Konsumtif pada Karyawan P.T Pionir Maxima Mutu Indonesia.
\end{abstract}

Kata Kunci: kampanye, korelasi, perilaku konsumtif 


\section{Pendahuluan}

Seiring dengan meningkatnya kesejahteraan masyarakat, maka tuntutan peningkatan kualitas kehidupan juga akan meningkat. Demikian pula hal yang terjadi pada sektor industri aplikasi Gojek yang merupakan salah satu perkembangan teknologi informasi dibidang transportasi, masyarakat pengguna jasa transportasi online tersebut menginginkan adanya banyak perubahan positif. Hampir sebagian masyarakat khususnya Jakarta Kebanyakan memiliki aplikasi ojek online sebagai alat transportasi dan sudah menjadi kebutuhan khusus setiap harinya. Hal ini juga dialami oleh karyawan-karyawan kantor,bukan hanya sebagai pemenuhan kebutuhan transportasi di dalam aplikasi ojek online tersebut sudah ada metode pembayaran digital yang melakukannya dengan cara scanning barcode.

Salah satu aplikasi yang banyak sekali penggunanya yaitu Gojek yang telah berhasil menciptakan uang digital yang bernama Go-Pay di dalam aplikasinya. GoPay yang merupakan dompet virtual untuk menyimpan saldo dan digunakan untuk membayar setiap transaksi di dalam aplikasi Gojek. Hasil riset yang dilakukan oleh lembaga survey JakPat yaitu Go-Pay telah bermitra dengan 28 institusi keuangan, serta telah diterima di lebih dari 240.000 rekan usaha di berbagai kota di Indonesia, $40 \%$ di antaranya adalah UMKM. Jumlah pengguna Go-Pay mencapai 79\%, dari jumlah responden yang menggunakan layanan keuangan digital. Hal ini juga menunjukan bahwa Go-Pay memiliki kontribusi yang besar dalam meningkatkan pemahaman masyarakat akan layanan keuangan digital (fintech) yang semakin tahun semakin meningkat.

Berdasarkan Laporan Fintech ini sejumlah 70,63\% masyarakat mengakui lebih paham mengenai layanan keuangan digital. Dompet elektronik termasuk teknologi yang belum banyak digunakan meskipun pengguna telah cukup mengenal berbagai macam metode pembayaran elektronik. Pertumbuhan transaksi Go-Pay sangat tinggi sejak pertama kali diluncurkan. Namun, hanya sedikit sekali penelitian yang sudah membahas tingkat penerimaan Go-Pay oleh pengguna di Indonesia. Tujuan penelitian ini adalah untuk mengetahui pengaruh Kampanye Go-Pay Pay Day food and beverage terhadap perilaku konsumtif karyawan P.T Pionir Maxima Mutu Indonesia.

Rumusan masalah dalam penelitian membahas Apakah Kampanye Go-Pay Pay Day food and beverage berpengaruh terhadap perilaku konsumtif karyawan P.T Pionir Maxima Mutu Indonesia?. Widayatmoko dalam jurnalnya mengungkapkan bahwa seseorang yang memiliki perilaku konsumtif akan membeli apa saja yang diinginkan tanpa memperdulikan jumlah uang yang akan dikeluarkan, Perilaku konsumtif ini dapat terus berkembang di dalam gaya hidup seseorang, tetapi gaya hidup konsumtif juga harus didasari dengan finansial yang memadai (dalam Harlie dan Widayatmoko, 2018).

\section{Metode Penelitian}

Metode penelitian yang digunakan oleh peneliti pada penelitian ini adalah metode korelasional yang digunakan untuk mengukur hubungan di antara berbagai variabel, meramalkan variabel tak bebas dari pengetahuan kita tentang variabel bebas, dan meratakan jalan untuk membuat rancangan penelitian eksperimental (Rakhmat, 2009: 31). Penelitian korelasi adalah suatu penelitian yang melibatkan tindakan pengumpulan data guna menentukan, apakah ada hubungan dan tingkat hubungan antara dua variabel atau lebih (Sukardi, 2009). 
Cyntia Triana Simanjuntak, H.H. Daniel Tamburian: Pengaruh Kampanye Go-Pay Day Food and Beverage terhadap Perilaku Konsumtif Pengguna (Survei Pada Karyawan PT. Pionir Maxima Mutu Indonesia)

\section{Populasi dan Sampel}

Populasi merupakan wilayah generalisasi yang terdiri atas subyek atau obyek uang memiliki karakter dan kualitas tertentu yang ditetapkan oleh seorang peneliti untuk dipelajari yang kemudian ditarik kesimpulannya (Sugiyono, 2017). Populasi dalam penelitian ini adalah karyawan yang bekerja di PT. Pionir Maxima Mutu Indonesia terletak di Mall Taman Anggrek Jakarta Barat, yang pernah atau sedang menggunakan aplikasi uang digital Go-Pay sebagai alat pembayaran food and beverage. Alasan peneliti melakukan penelitian di PT Pionir Maxima Mutu Indonesia dikarenakan lokasi PT tersebut terletak di dalam Mall yang sangat memudahkan karyawan untuk melakukan transaksi saat Go-Pay Pay Day food and beverage berlangsung.

Sampel merupakan bagian dari populasi yang memiliki ciri-ciri atau keadaan tertentu yang akan diteliti. Sampel juga dapat didefinisikan sebagai sebuah anggota populasi yang dipilih dengan menggunakan prosedur tertentu sehingga diharapkan juga mewakili suatu populasi (Martono, 2011). Teknik pengambilan sampel yang digunakan adalah nonprobability sampling. Nonprobability sampling adalah teknik pengambilan sampel yang tidak memberi peluang/kesempatan yang sama bagi setiap unsur (anggota) populasi untuk dipilih menjadi anggota sampel. Jenis teknik pengambilan sampelnya adalah saturation sampling. Saturation sampling adalah metode dalam mengambil sampel yang dimana harus mengikutsertakan semua dari anggota populasi, dimana memberikan kuesioner online kepada para pengguna GoPay.

\section{Operasionalisasi Konsep}

Tabel 1. Operasional Variabel X

\begin{tabular}{|c|c|c|}
\hline Variabel & Dimensi & Indikator \\
\hline \multirow[t]{3}{*}{$\begin{array}{l}\text { Kampanye }(X) \\
\text { Teori dari } \\
\text { Newsom, Scott, } \\
\text { dan Turk 1997 } \\
\text { (Ruslan,2013) }\end{array}$} & Public awareness & $\begin{array}{l}\text { 1. Kampanye Go-Pay Pay Day food and } \\
\text { beverage dibuat untuk meningkatkan } \\
\text { kesejahteraan pengguna. } \\
\text { 2. Didasari dengan kepentingan perusahaan. }\end{array}$ \\
\hline & Offer information & $\begin{array}{l}\text { 1. Kampanye GO-PAY PAY DAY food and } \\
\text { beverage melakukan penawaran secara } \\
\text { mendalam. } \\
\text { 2. Pengguna dengan mudah mengetahui } \\
\text { informasi yang disampaikan. }\end{array}$ \\
\hline & Public education & $\begin{array}{l}\text { 1. Meningkatkan pemahaman akan layanan } \\
\text { keuangan digital }\end{array}$ \\
\hline
\end{tabular}

Reinforce the attitudes and behavior

1. Dapat meningkatkan produktivitas 
Tabel 2. Operasional Variabel Y

\begin{tabular}{|c|c|c|}
\hline \begin{tabular}{l}
\multicolumn{1}{c}{ Variabel } \\
PerilakuKonsumtif \\
(Y) \\
Teori dari Lina, \\
Rasyid 1997 \\
(Wardhani,2009)
\end{tabular} & Dimensi & Indikator \\
\hline \multirow[t]{3}{*}{$\begin{array}{l}\text { PerilakuKonsumtif } \\
\text { (Y) } \\
\text { Teori dari Lina, } \\
\text { Rasyid } 1997 \\
\text { (Wardhani,2009) }\end{array}$} & Impulsive buying & $\begin{array}{l}\text { 1. Pola konsumsi yang biasanya } \\
\text { dilakukan secara spontan. } \\
\text { 2. Didasari keinginan sesaat. } \\
\text { 3. Dipengaruhi oleh lingkungan sekitar }\end{array}$ \\
\hline & Wasteful buying & $\begin{array}{l}\text { 1. Tidak realistis dan cenderung boros. } \\
\text { 2. Menghamburkan banyak dana }\end{array}$ \\
\hline & $\begin{array}{l}\text { Non rational } \\
\text { buying }\end{array}$ & $\begin{array}{l}\text { 1. Ingin mengikuti trend terkini. } \\
\text { 2. Hanya untuk kesenangan semata. }\end{array}$ \\
\hline
\end{tabular}

\section{Metode Pengumpulan Data}

Menurut Riduwan (2011), metode pengumpulan data adalah "teknik atau caracara dimana peneliti menggunakannya untuk mengumpulkan data". Metode pengumpulan data yang penulis lakukan dalam penelitian ini adalah.

\section{Kuesioner}

Satu teknik pengumpulan informasi yang memungkinkan analisis mempelajari sikap-sikap, keyakinan, perilaku, dan karakteristik beberapa orang utama di dalam organisasi yang bisa terpengaruh oleh sistem yang sudah ada (Siregar, 2013, p44). Metode kuesioner ini dilakukan melalui penyebaran kuesioner online yang dapat diisi langsung oleh responden melalui telepon genggam, yang terdiri dari karyawan PT. Pionir Maxima Mutu Indonesia yang menggunakan layanan GO-PAY, tepatnya pada saat kampanye GO-PAY PAY DAY berlangsung.

\section{Studi Pustaka}

Metode studi pustaka adalah teknik pengumpulan yang dilakukan untuk menyusun landasan teoritis penelitian melalui sumber referensi yang berkaitan dengan penelitian ini.

\section{Skala Pengukuran Data}

Menurut Sugiyono (2011: 134) Skala Likert digunakan untuk mengukur sikap, pendapat, dan persepsi seseorang atau sekelompok orang tentang fenomena sosial, yang ada dalam penelitian telah ditetapkan secara spesifik oleh peneliti.

Jawaban setiap instrumen yang menggunakan skala likert mempunyai gradasi dari sangat positif sampai sangat negatif, yang dapat diberi skor sebagai berikut :

\section{Teknik Pengolahan \& Analisis Data Uji Validitas}

Uji validitas bertujuan untuk mengukur valid atau tidaknya suatu pernyataan untuk menyatakan bahwa butir valid atau tidak, digunakan nilai patokan 0,2 dan dibandingkan dengan angka-angka yang ada pada kolom Corrected Item - Total Correlation. Bila angka korelasi di atas 0,2 maka dinyatakan valid (Nisfiannoor, 2013).

\section{Uji Reliabilitas}

Menurut Sugiyono (2017) uji reliabilitas adalah sejauh mana hasil pengukuran dengan menggunakan objek yang sama, akan menghasilkan data yang sama. Syarat 
Cyntia Triana Simanjuntak, H.H. Daniel Tamburian: Pengaruh Kampanye Go-Pay Day Food and Beverage terhadap Perilaku Konsumtif Pengguna (Survei Pada Karyawan PT. Pionir Maxima Mutu Indonesia)

minimum untuk dinyatakan reliabel adalah apabila hasil korelasinya 0,7 atau lebih. Tetapi apabila nilai korelasinya di bawah 0,7 maka item tersebut dinyatakan tidak reliabel (Sugiyono, 2017).

\section{Uji Normalitas}

Metode pengujian yang digunakan untuk menguji normalitas data pada penelitian ini adalah dengan uji One Sample Kolmogorov- Smirnov. Dalam uji Kolmogorov-Smirnov (Ghozali, 2016).

a. Nilai signifikan $>0.05$ berarti data residual berdistribusi normal

b. Nilai signifikan $<0.05$ berarti data residual tidak berdistribusi normal.

\section{Teknik Keabsahan Data}

Setelah kuesioner disebar, data yang didapatkan akan diolah menggunakan Aplikasi SPSS for Windows versi 20.

\section{Uji Koefisien Korelasi}

Koefisien korelasi (R) adalah bilangan yang menyatakan bahwa terdapat kekuatan hubungan antara dua variabel atau lebih atau juga dapat menentukan jatah dari kedua variabel (Syofian, 2013).

Berikut adalah tingkat korelasi dan kekuatan hubungan :

$0,00-0,199=$ Sangat Lemah

$0,20-0,399=$ Lemah

$0,40-0,599=$ Cukup

$0,60-0,799=$ Kuat

$0,80-0,1000=$ Sangat Kuat

Koefisien korelasi adalah pengukuran statistik kovarian atau asosiasi antara dua variabel. Besarnya koefisien korelasi berkisar antara $+1 \mathrm{~s} / \mathrm{d}-1$. Koefisien korelasi menunjukkan kekuatan (strength) hubungan linear dan arah hubungan dua variabel acak. Jika koefisien korelasi positif, maka kedua variabel mempunyai hubungan searah. Artinya jika nilai variabel $\mathrm{X}$ tinggi, maka nilai variabel $\mathrm{Y}$ akan tinggi pula. Sebaliknya jika koefisien korelasi negatif, maka kedua variabel mempunyai hubungan terbalik. Artinya, jika nilai variabel $\mathrm{X}$ tinggi, maka nilai variabel $\mathrm{Y}$ akan menjadi rendah (Sarwono, 2006).

\section{Koefisien Determinasi $\left(R^{2}\right)$}

Koefisien Determinasi $\left(R^{2}\right)$ yang pada umumnya mengukur sejauh mana kemampuan model dan menerangkan variabel - variabel terikat. Nilai koefisien determinasi adalah di antara nol dan satu. Nilai $R^{2}$ yang kecil berarti kemampuan variabel - variabel independen dalam menjelaskan variabel - variabel dependen sangat terbatas, nilai yang mendekati satu berarti variabel - variabel independen memberikan hampir semua informasi yang dibutuhkan untuk memprediksi variabel - variabel dependen (Ghozali, 2007).

\section{Analisis Regresi Linear Sederhana}

Analisis Regresi digunakan untuk melakukan penembakan seberapa besar nilai variabel dependen jika nilai variabel independen diganti sedemikian rupa. Menurut Sugiyono (2012), rumus analisis regresi sederhana sebagai berikut :

$$
\mathbf{Y}=\mathbf{a}+\mathbf{b X}
$$


Keterangan :

$\mathrm{Y}=$ Variabel dependen

$\mathrm{X}=$ Variabel independen

$\mathrm{a}=$ konstanta

$\mathrm{b}=$ koefisien regresi

\section{Uji Hipotesis}

1. Jika terdapat nilai Sig $<0.05$ maka variabel bebas berpengaruh signifikan terhadap variabel terikat.

2. Jika terdapat nilai Sig $>0.05$ maka variabel bebas tidak berpengaruh signifikan terhadap variabel terikat (Sugiyono, 2012).

\section{Hasil Temuan dan Diskusi}

Tabel 3. Hasil Uji Validitas

\begin{tabular}{llll}
\hline Variabel & Butir Indikator & $\begin{array}{l}\text { Corrected } \\
\text { Item Total } \\
\text { Correlation }\end{array}$ & Keterangan \\
\hline Kampanye (X) & Indikator 1 & 0.839 & Valid \\
\cline { 2 - 4 } & Indikator 2 & 0.782 & Valid \\
\cline { 2 - 4 } & Indikator 3 & 0.639 & Valid \\
\cline { 2 - 4 } & Indikator 4 & 0.706 & Valid \\
\cline { 2 - 4 } & Indikator 5 & 0.667 & Valid \\
\cline { 2 - 4 } & Indikator 6 & 0.635 & Valid \\
\hline Perilaku Konsumtif & Indikator 7 & 0.719 & Valid \\
\cline { 2 - 4 } (Y) & Indikator 8 & 0.698 & Valid \\
\cline { 2 - 4 } & Indikator 9 & 0.699 & Valid \\
\cline { 2 - 4 } & Indikator 10 & 0.753 & Valid \\
\cline { 2 - 4 } & Indikator 11 & 0.771 & Valid \\
\cline { 2 - 4 } & Indikator 12 & 0.780 & Valid \\
\cline { 2 - 4 } & Indikator 13 & 0.787 & Valid \\
\hline
\end{tabular}

Berdasarkan Tabel 3, hasil dari uji validitas menunjukkan setiap pernyataan dari variabel Kampanye (X) dan Perilaku Konsumtif (Y) dinyatakan valid, karena nilai dari corrected item total correlation lebih besar dari patokannya, yaitu 0.2.

\section{Hasil Uji T}

Hal ini dapat dikatakan hasil uji $\mathrm{T}$ pada variabel $\mathrm{X}$ adalah Ho ditolak dan $\mathrm{Ha}$ diterima, artinya terdapat pengaruh Kampanye GO-PAY PAY DAY food and beverage terhadap Perilaku Konsumtif. Nilai Sig $<\alpha$ yaitu $0.000<0.05$, maka dapat diartikan bahwa Kampanye Go-Pay Pay Day food and beverage berpengaruh signifikan terhadap Perilaku Konsumtif. Maksudnya adalah hasil dari penelitian tidak hanya berlaku untuk sampel tetapi hasil penelitian juga akan berlaku jika dilakukan oleh populasi. 
Cyntia Triana Simanjuntak, H.H. Daniel Tamburian: Pengaruh Kampanye Go-Pay Day Food and Beverage terhadap Perilaku Konsumtif Pengguna (Survei Pada Karyawan PT. Pionir Maxima Mutu Indonesia)

\section{Kesimpulan}

Berdasarkan hasil pembahasan dan hasil penelitian, maka penulis menarik kesimpulan sebagai berikut :Kampanye Go-Pay Pay Day food and beverage memiliki hubungan positif dan signifikan terhadap Perilaku Konsumtif pada Karyawan P.T Pionir Maxima Mutu Indonesia, Kampanye Go-Pay Pay Day food and beverage memiliki hubungan yang signifikan terhadap Perilaku Konsumtif pada Karyawan P.T Pionir Maxima Mutu Indonesia.Hal ini dapat dikatakan hasil uji T pada variabel X adalah Ho ditolak dan Ha diterima, artinya terdapat pengaruh Kampanye Go-Pay Pay Day food and beverage terhadap Perilaku Konsumtif. Nilai Sig $<\alpha$ yaitu $0.000<0.05$, maka dapat diartikan bahwa Kampanye Go-Pay Pay DAY food and beverage berpengaruh signifikan terhadap Perilaku Konsumtif.

Kampanye Go-Pay Pay Day food and beverage memiliki kontribusi yang besar dalam meningkatkan pemahaman masyarakat akan layanan keuangan digital dan peningkatan penjualan.Efek yang ditimbulkan adalah perilaku konsumsi masyarakat yang telah bergeser dari kebutuhan primer ke kebutuhan sekunder, dan cenderung bersikap konsumtif.

Memanfaatkan temuan penelitian mengenai faktor yang berdampak positif terhadap pembentukan kampanye Go-pay, Tetap mempertahankan kampanye Go-pay untuk memenuhi kebutuhan dan kesejahteraan pengguna, Mengembangkan faktor lain yang turut menjadi penyebab perilaku konsumtif seseorang.

\section{Ucapan Terima Kasih}

Penulis mengucapkan terima kasih kepada Fakultas Ilmu Komunikasi Universitas Tarumanagara yang telah memberikan tugas untuk pembuatan jurnal ini, Kepada Pimpinan P.T Pionir Maxima Mutu Indonesia yang telah memberikan ijin untuk menjadikan survei penelitian serta teman - teman seperjuangan yang membantu dan memberikan semangat selama penulis melakukan penelitian.

\section{Daftar Pustaka}

Cindy, Eko, dan Lusia. (2017). Analisis Tanggapan Digital Native Menonton Kampanye Samyang Challenge (Studi Terhadap Mahasiswa Universitas Tarumanagara). Jurnal Komunikasi Vol.1, No.2.

Cita Cania, Silva. (2018). Faktor-faktor Yang Mempengaruhi Penggunaan Layanan GO-PAY Pada Pelanggan Maupun Pengemudi GO-JEK. Jurnal Pendidikan Ekonomi UII.

Effendy, Onong Uchjana. (2009). Ilmu Komunikasi: Teori dan Praktek. Bandung : PT. Remaja Rosdakarya.

Fattah, Indriayu, \& Sunarto. (2018). Pengaruh Literasi Keuangan dan Pengendalian Diri Terhadap Perilaku Konsumtif Siswa SMA Muhammadiyah 1 Karanganyar. Jurnal Pendidikan Bisnis dan Ekonomi, Vol. 4 No. 1:11-21.

Ghozali. (2007). Aplikasi Analisis Multivariate dengan Program SPSS. Badan Penerbitan Universitas Diponegoro. Semarang.

Hamidi. (2010). Metode Penelitian Kualitatif. Malang: UMM Press.

Harlie,Widayatmoko. (2018). Analisis Wacana Perilaku Konsumtif Dalam Film Crazy

Rich Asian. Jurnal Komunikasi 
Vol. 4, No. 1, Maret 2020, Hal 113-120

Hotpascaman.S. (2010). Hubungan Perilaku Konsumtif Dengan Konformitas Pada Remaja. Skripsi Prodi Psikologi. Universitas Sumatra Utara: Tidak Diterbitkan. 